\title{
Enterprise Internal Control Based on Corporate Risk Management
}

\author{
Wei Wang \\ Shandong Agriculture Engineering University, Ji'nan, 250100, China
}

\begin{abstract}
Keywords: Corporate risk; Enterprise management; Enterprise internal control; Supervision system
\end{abstract}
\begin{abstract}
If the enterprise internal control lacks of effective management, the enterprise safety will be threatened, which may cause serious influence on the enterprise and even let an enterprise with strong capital instantly leave from the market. Therefore, the enterprise internal control is made for the purpose of further protecting the safety and completeness of enterprise economic resource, avoid the risk brought by the market to enterprise, and continuously promote enterprise development and further improve enterprise image. In order to avoid the risk, “development corporate strategy, carry out process control, and enhance personnel supervision” becomes a standard for most of corporate management systems at present.
\end{abstract}

\section{Introduction}

In order to realize development, one company must play game with risk. There will be loss in case of risk; such kind of loss is potential and may turn into reality at certain stage. Except for potential crisis, this kind of risk can also bring certain benefits to enterprise, which is just the charm of enterprise operation and enterprise risk management. Simply speaking, it is a gaming between benefit and potential loss. To draw on advantages and avoid disadvantages is the instinct of human thinking, and also a criterion for an enterprise to game with the risk. In recent years, the construction and perfection of enterprise internal control system become a foundation which determines whether the enterprise can realize a long-term development, and how to establish an effective enterprise control system also becomes the topic in operation and management strategy. The key point of internal control is how the enterprise carries out reasonable division of labor, and the function planning and implementation form become the core points of internal control. The purpose of enterprise internal control is to enhance enterprise management and improve enterprise economic benefit. "To realize more perfect internal control under rational risk management” is also the main content of this paper.

\section{Enterprise internal control}

\section{Enterprise internal control}

We start the research from historical development of enterprise internal control. As for evolution of internal control, what we mention at the beginning is the world power "the United States". Today, the internal control mechanism developed in all countries in the world is the result of American research and practical application of internal control, which is widely recognized by all countries. The internal control systems of CSRC (China Securities Regulatory Commission), CBRC (China Banking Regulatory Commission), People's Bank of China, and Ministry of Finance are all quoted from American report system, that is, a big achievement system of American internal control research. In recent 100 years, American internal control has obtained rapid development and improvement, which benefits from mutual fusion between different subjects and continuous reform of resource allocation mode. The tight combination of theory and practice gives us an important enlightenment, that is, how to link a scientific way and basic cell of social development with enterprise resource allocation; instead of changing theory as "theory", we shall change the theory as a kind of productivity; this is the correspondence to introduction and final practice of internal control theory. An event is completed by many people and through many stages and levels; at this time, we can carry out mutual checking, or check the previous process in later process so as to improve the previous process. This is the important function of division of labor on enterprise internal control, and this 
method is gradually applied in enterprise finance, and then the internal control and balance mechanism appears; this is the beginning of enterprise internal control.

\section{Influence of risk on enterprise}

\section{Risk management concept}

The enterprise risk management refers to a kind of management mode which carries out recognition, analysis, measurement, and evaluation on various kinds of risks which may happen in the enterprise, and carries out effective standardization and improvement to guarantee the supreme interests of one enterprise. The enterprise internal control is made for the purpose of controlling the overall risk in enterprise development and serving for various kinds of risk occurred in different stages of enterprise development.

\section{Enterprise risk}

In the resource allocation and operation process, there will be difference and gap between the goal and actual condition; this is the uncertainty in enterprise operation, and such uncertainty is the enterprise risk. Since the enterprise is established, the fraud and cheating always exist around the enterprise management, and the internal control is the source of problem, thus a series of remedy measures have been formulated. However, the fact proves that there also exist many problems in the decision-making mechanism of enterprise governance except for problematic balance of rights.

\section{How to know enterprise risk}

In the process of enterprise development, the uncertainty that the enterprise may meet different problems and difficulties causes enterprise risk, and the result caused by the risk may be "benefit" or "loss". Therefore, through changing some important factors in enterprise development, it is able to influence enterprise benefits. From perspective of enterprise resource allocation and operation process, the risks in enterprise operation can be divided into three layers: the first layer is change of mode, the second layer is implementation of mode, and the third layer is the information which influences decision-making. In these three layers, the most critical thing is to develop enterprise operation and improve economic benefit through implementing enterprise internal control.

\section{Purpose of enterprise internal control under corporate risk management}

With enterprise growth, the enterprise process shall be more standard, and a scientific financial order can guide enterprise financial income; this importance will become more obvious with the expansion of enterprise. The internal control is actually a kind of organization form in which one economic unit has mutual dependence with other economic unit in an enterprise, and it has the functions of division of labor, cooperation, and restriction. The purpose of internal control is to improve operation and management, improve overall development speed of enterprise, and enhance enterprise economic benefit. Therefore, the internal control develops with development of enterprise economic management and it is gradually perfected. The initial control appears in financial department in order to ensure correct accounts and clear flow of enterprise property. However, with the development of commodity economy and increasingly complicated economic activities, the internal control system is gradually transferred from finance department to whole enterprise. Currently, the supervision system which includes internal supervision, government supervision, and social supervision has been formed in China. However, the supervision effect is not ideal; as one of important part of internal control, the internal auditing is not clearly set in many enterprises, and no corresponding personnel of auditing institution is provided. Therefore, the enterprises will have no great development in a long time. If the enterprises are equipped with auditing institutions and auditing personnel, they can carry out strict review on financial practice, improve enterprise operation quality, and make enterprises become larger and stronger. 


\section{How to carry out enterprise internal control}

To enhance internal control on enterprise monetary capital

To establish related post separation system

The related posts refer to mutually related posts in one enterprise: for example, both accounting personnel and cashier are involved in enterprise fund; at this time, if one person manages accounting and finance, it is very likely that the error, fraud, and shielding will happen. The related posts shall be not undertaken by one person, and the separation system of related posts is the basic system of internal control of middle and small-sized enterprises. However, in the actual enterprise operation, the situation that the personnel is insufficient often happens. Despite of existence of such situation, in order to realize better enterprise development, we shall still pay attention to the separation of several posts: authorization post and execution post, business handling post and property keeping post, financial management post and accounting post, etc.

To perfect authorization and approval system

In order to ensure transparent and open fund flow, the more attention shall be paid to approval on expenditure and use of enterprise internal fund, and the standard, complete, and systematic approval procedure can standardize the fund utilizing, and avoid embezzlement to certain degree. However, the perfection of systematic approval procedure specifically includes: specifying the authorizers' privilege, stipulating approvers' range of approval, authorizing approval procedure, specifying approval process, and avoiding falsification. In the process of establishing and perfecting this system, one of most fundamental requirements is to establish the separation system of related posts and enhance enterprise supervision.

To establish a perfect currency management system

The enterprise lifeblood is closely tied on enterprise fund flow; therefore, in order to realize the maximum enterprise economic benefit, we shall pay attention to enterprise production, operation, and fund maintenance. To establish a complete currency management system can help to carry out budget on enterprise operation planning, thus it is able to make prevention against possible economic difficulties the enterprise may meet in the future, help the enterprise to carry out income prediction, and be convenient for estimating the cost of next operation activity in advance so as to ensure enterprise's normal operation and long-term development. The establishment of a perfect currency management system is mainly reflected at following aspects:

1). Make enterprise budget and planning of income and expense. Carry out prediction on enterprise budget, income and expense, and further determine enterprise operation cost and strategy to effectively operate the enterprise and expand the production and sales of enterprise products.

2). Determine the handling process of cash business. In the face of cash transaction, how do the accounting and financial personnel keep account? How do they handle the fund? When is the fund deposited into bank? How do they use the fund? All of those are problems which shall be considered in enterprise work, and how to handle enterprise fund is also the key point to which the attention shall be paid in enterprise internal control.

To establish bill and seal management system

The bill and seal are very important for enterprises; they are not only the guarantee for enterprise fund flow, but also the representative of enterprise credit and enterprise brand. Therefore, the enterprises shall pay attention to fund circulation and registration process, and establish special management personnel to manage the bills. Firstly, the enterprise shall enhance the control on bills and use them according to the sequence of fixed serial number. Secondly, the enterprises shall enhance the safekeeping on blank bills and avoid unclear registration of accounts caused due to human factor. Thirdly, the enterprises shall enhance the management on the seal, avoid occurrence of private use or misuse, and avoid the problems caused due to loss or misuse of common seal.

To enhance the education on enterprise personnel and improve personnel's quality level

Through improving accounting personnel's quality, it is able to effectively reduce occurrence of problems from perspective of employees. The development of one enterprise can't be separated from individuals; in order to realize normal enterprise operation, the enterprise personnel's quality level 
must be improved. For example, the employees must hold corresponding qualification certificate, just like the situation that the accounting personnel shall have Certificate of Accounting Professional, so as to improve the education on enterprise personnel from perspective of professional skills. However, this aspect of education is insufficient; the enterprises shall provide their employees with skill training chances and places, carry out education activities on them, and improve their collective sense to enterprise; this is the effective means of enterprise internal control.

\section{To enhance the exertion of inspection and supervision system}

As for a country, there is separation of the three powers, that is, legislation, administration, and justice, so as to realize mutual restraints and balance. As for one enterprise, it shall have good execution department and restricting supervision department. To establish a good internal supervision and management department is one of necessary condition for an enterprise to carry out internal control. Therefore, according to enterprise scale, the different number of people are selected to participate in the construction of supervision department, which is a measurement to judge whether the enterprise operation is reasonable and legal. Except for internal setting of supervision department, the enterprises can regularly employ accounting talents and other talents beyond company to carry out supervision and review on enterprise capital and operation for convenience that the enterprise work can be smoothly done. In enterprise supervision, the following specific ways of operation can be adopted:

1). Irregular checking. It is able to carry out sudden checking on accounts, accounting records, and employees' work condition for convenience of restoring employees' daily work condition and actual condition of enterprise operation.

2). Pay attention to checking enterprise accounts and bank bills, and ensure clear and transparent enterprise fund. Simply speaking, it is required to realize " $4 \mathrm{~W} 1 \mathrm{H}$ " effect, that is, knowing how much is the enterprise fund (WHAT), why the fund is used (WHY), when the fund is used (WHEN), who use the fund (WHO), and how the fund is used (HOW).

3). Pay attention to check whether the accounts are true. In order to avoid repeated checking and false accounts, the enterprises shall often evaluate whether the accounts are true, which not only enhances the supervision on accounting personnel, but also further enhances internal control.

\section{Conclusion}

In conclusion, in order to realize normal enterprise operation and ensure the maximization of enterprise economic benefit, we shall pay attention to the function of internal control system. However, to perfect internal control system, standardize enterprise operation process and system, ensure asset stability and clear fund flow is the only way to further enhance enterprise construction and promote enterprise economic growth. The economic development of one enterprise drives the reasonable development of many enterprises; in this way, it is able to promote the development of whole social economy as a whole, and this is also the important function of internal control mechanism on whole enterprise and social development. There is the saying that the powers are divided into six ministries in ancient time, and also the saying of separation of three powers in modern time; those cases tell us that it is able to realize enterprise management only through balance of power, and the level of an enterprise is determined by the level of its management. China's development also can't be separated from those enterprises with deep cultural deposits, and the scientific and reasonable internal control mechanism of one enterprise is also an important key which promotes China's rapid development.

\section{Acknowledgments}

This paper is the research result of special accounting project of Shandong provincial social science planning research (Project No.: 11CKJJ18). 


\section{References}

[1] Zhang Jianwei, Sheng Zhenjiang: Modern Enterprise Management, Enterprise Management, 2011 (4): 25.

[2] Dai Shufen: Management Course, Enterprise Management, 2011 (7): 12.

[3] Tao Wanting: Construct Accounting Restriction Mechanism: Internal Control Methods for Monetary Capital of Middle and Small-sized Enterprises, Theoretic Observation, 2012 (4): 30.

[4] Shi Xiaochuan: Common Problems in Monetary Capital of Middle and Small-sized Enterprises and Countermeasures, Henan Science \& Technology, 2011 (7): 15-45.

[5] Hong Yan: Discussion on Basic Requirements for Separation of Incompatible Posts in Internal Control, New Finance Economics, 2013 (8): 14-34.

[6] Zhao Hua: Research on Internal Control of Enterprise Cost, Southwestern University of Finance and Economics, 2011 (08): 12-14.

[7] Yuan Yong: Research on Internal Control of Monetary Capital of Chinese Enterprises, Journal of Wanxi University, 2013 (07): 19-41. 